IJMS 23 (2), 97-124 (2016)

\title{
KEPERLUAN PEMEGANG KEPENTINGAN INSTITUSI ZAKAT TERHADAP ITEM MAKLUMAT PELAPORAN PRESTASI
}

\author{
NOOR FADZILAH SHAFIE \\ Majlis Agama Islam Wilayah Persekutuan (MAIWP) \\ RUHANITA MAELAH \\ NORIDA BASNAN \\ Fakulti Ekonomi dan Pengurusan \\ Universiti Kebangsaan Malaysia
}

\begin{abstract}
Abstrak
Zakat memainkan peranan penting dalam ekonomi Islam sebagai salah satu alat ekonomi bagi memartabatkan golongan miskin. Justeru, keyakinan pembayar zakat terhadap proses pengurusan zakat yang dilakukan oleh institusi zakat adalah penting dalam meningkatkan jumlah kutipan zakat. Keyakinan pembayar zakat ini dan pihak awam secara umumnya boleh ditingkatkan melalui pendedahan maklumat kewangan dan prestasi institusi zakat secara telus dan menyeluruh. Bagi meningkatkan keyakinan dan seterusnya menjelaskan akauntabiliti institusi zakat kepada pelbagai pihak pemegang kepentingannya, pelaporan prestasi yang mendedahkan maklumat mengikut keperluan pemegang kepentingan merupakan salah satu medium penting yang telah diiktiraf dalam kebanyakan kajian lepas. Kajian ini bertujuan untuk mengkaji keperluan pemegang kepentingan terhadap pendedahan item maklumat di dalam pelaporan prestasi institusi zakat. Tujuan ini dicapai dengan melaksanakan kaedah tinjauan soalselidik terhadap tiga kumpulan pemegang kepentingan iaitu pembayar zakat, penerima zakat dan pentadbir zakat. Hasil kajian menunjukkan secara keseluruhan pemegang kepentingan menyatakan maklumat kewangan dan bukan kewangan adalah penting untuk didedahkan di dalam pelaporan prestasi dan tiada perbezaan keperluan pendedahan bagi kebanyakan item maklumat di kalangan pembayar, penerima dan pentadbir zakat. Hasil kajian boleh dijadikan panduan kepada pihak institusi zakat dan agensi kerajaan lain bagi meningkatkan ketelusan dan memperkasakan akauntabiliti dalam mencapai urus tadbir ekonomi yang adil.
\end{abstract}

Kata kunci: Zakat, pelaporan prestasi, pemegang kepentingan, akauntabiliti. Klasifikasi JEL: H75, H83, M41

Received: 05/03/2016 Revise: 01/08/2016 Accepted: 25/10/2016 Publish: 15/12/2016 


\begin{abstract}
Zakat plays an important role in the economy of Islam because it is one of the essential tools to elevate the poor. The confidence of zakat payers on the collection process and distribution is important in increasing the amount of zakat collection. In general, zakat payers' and the public's confidence can be gained by full and transparent disclosure of financial information and performance of the zakat nstitution. Consequently, to enhance confidence and discharge accountability of the zakat institutions to various stakeholders, performance reporting that discloses information according the needs of stakeholders is one of the important media which has been recognized in most past researches. Therefore, the objective of this study is to examine the needs of stakeholders on the importance of disclosure for information items in the performance reports of zakat institutions. This purpose was achieved by conducting a questionnaires survey on three groups of stakeholders; payers, recipients and administrators of zakat. The findings show that stakeholders are concerned with the financial and non-financial information to be disclosed in the performance reporting and there is no difference in the importance of disclosure of information item by payers, recipients and administrators of zakat. The findings of this study can be used as a guidence by the zakat institutions and other government agencies in order to improve transparency and strengthen accountability to achieve fair economic governance.
\end{abstract}

Keywords: Zakat Instituitions, performance reporting, stakeholders, accountability. JEL Classification: H75, H83, M41

\title{
Pengenalan
}

Reformasi di dalam sektor awam melalui Pengurusan Awam Baru (New Public Management-NPM) telah memberi penekanan kepada pelaksanaan teknik-teknik pengurusan sektor swasta di sektor awam seperti memperkenalkan perakaunan akruan, pengurusan berdasarkan kecekapan, berdaya saing dan responsif kepada keperluan dan kepentingan awam. Dalam aspek ini, ketelusan dan akauntabiliti dilihat sebagai sebahagian agenda utama NPM (Zaharia, 2012; Groot \& Budding, 2005). Melalui NPM, pengurusan berasaskan keberhasilan (Result Based Management-RBM) diperkenalkan dimana ianya memberi tumpuan kepada prestasi, yang mana pelaporan prestasi merupakan elemen utamanya (Saldanha, 2004; McDavid \& Huse, 2011). 
Dalam sektor awam, pelaporan prestasi yang dikeluarkan kepada pihak awam adalah penting dan merupakan satu cara untuk memastikan kerajaan bertanggungjawab dan telus. Pelaporan prestasi perlu dikeluarkan mengikut saluran yang bersesuaian seperti melalui laporan tahunan, laman web organisasi, kad laporan dan kenyataan akhbar serta mengikut tempoh masa yang tertentu (Grosso \& Ryzin, 2011). Dengan adanya pelaporan mengenai prestasi, pihak awam akan merasa lebih yakin dan dihargai apabila mengetahui wang awam yang diamanahkan kepada sesebuah sektor awam telah diuruskan dengan baik dan sempurna (Engku Ismail,Mohamad Sharofi, Syed Soffian, Siti Zabedah, \& Zarifah, , 2011). Sebagai salah sebuah organisasi sektor awam, pelaporan prestasi yang dikeluarkan oleh institusi zakat dilihat sangat penting dalam mengkomunikasikan peranannya kepada semua pemegang kepentingan termasuk pihak awam.

Zakat memainkan peranan yang sangat besar di dalam masyarakat Islam sebagai penyucian diri, harta dan masyarakat (Qhardawi, 2007). Ia menyucikan diri si miskin daripada perbuatan meminta-minta dan hasad dengki kepada golongan yang berada. Keadaan sosial akan menjadi lebih runcing lagi sekiranya golongan miskin ini melakukan pelbagai jenayah sosial seperti pencurian, pecah rumah dan lain-lain kesan daripada himpitan kemiskinan. Menurut Imam Abu Hanifa, mengagihkan zakat kepada semua lapan asnaf yang dinyatakan dalam Al-Quran adalah bukan satu kemestian. Kutipan zakat boleh dibahagikan kepada satu asnaf sahaja walaupun terdapat asnaf-asnaf yang lain (Hairunnizam, Mohd Ali \& Sanep, 2005).

Objektif zakat adalah untuk menegakkan keadilan ekonomi dan sosial iaitu menyumbang kepada pembasmian kemiskinan dan penyelesaian kepada masalah sosial (Norazlina \& Abdul Rahim, 2011; Patmawati, 2008; Qhardawi, 2007). Bagi mencapai objektif ini, institusi zakat ditubuhkan sebagai institusi awam yang bertanggungjawab untuk mengutip dan mengagih zakat secara cekap serta menjadi perantara antara pembayar dan penerima zakat (Hasan \& Syawal, 2007).

Institusi zakat adalah organisasi bukan berasaskan keuntungan yang ditubuhkan untuk menguruskan kutipan dan agihan dana zakat. Institusi zakat mula diberi perhatian dalam meningkatkan status sosio-ekonomi negara dan menghapuskan jurang kemiskinan terutamanya di kalangan masyarakat Islam. Namun, keyakinan yang rendah terhadap kecekapan institusi zakat sering dipertikaikan 
sehingga menyebabkan ramai golongan pembayar zakat enggan membayar zakat atau terus membayar kepada asnaf tanpa melalui institusi zakat sebagai pengantara (Hairunnizam, Sanep, \& Radiah, 2009; Patmawati, 2008; Azman, Mohammad Alias, \& Syed Mohd Najib 2012; ).

Kajian lepas mendapati zakat tidak diagihkan secara efektif oleh institusi zakat (Mohd Dahan, 1998) dan berlaku pecah amanah wang zakat dan pengurusan yang tidak cekap (Mahmood Zuhdi, 2003; Harunnizam \& Radiah ,2010). Untuk mengatasi masalah ini, pengagihan zakat perlu dinilai oleh pembayar zakat secara terbuka (Mohd Dahan, 1998) dan satu pengukuran prestasi diperlukan untuk memenuhi objektif zakat (Abdul Rahman, 2007). Htay dan Salman (2014) mencadangkan pendedahan maklumat pengutipan dan pengagihan zakat oleh institusi zakat melalui pelaporan kewangan bagi menjelaskan akauntabilitinya kepada pemegang kepentingan terutama pembayar dan penerima zakat. Selain maklumat kewangan, institusi zakat juga dilihat perlu mengkomunikasikan prestasinya dalam bentuk maklumat bukan kewangan terutama aktiviti kutipan dan agihan zakat bagi membolehkan pemegang kepentingan mengetahui ke mana dan bagaimana dana zakat disalurkan. Pelaporan prestasi dilihat sebagai satu mekanisma untuk mendedahkan maklumat kewangan dan bukan kewangan institusi zakat kepada semua pemegang kepentingannya termasuk pembayar zakat selari dengan pengiktirafan kajian-kajian lepas (Tooley, Hooks \& Norida, 2010; Hooks, Tooley \& Norida, 2012; Hyndman \& Anderson, 1995; Lapsley, 1992; Stoetzer \& Hilger, 2011) terhadap pelaporan prestasi sebagai mekanisma penting bagi sesebuah organisasi menjelaskan akauntabilitinya kepada pelbagai pemegang kepentingan.

Kajian lepas berkaitan institusi zakat di Malaysia lebih tertumpu kepada prestasi agihan zakat, kecekapan institusi zakat dan akauntabiliti dalam agihan zakat serta berkaitan pengenalpastian masalah dan isu institusi zakat (Mohammed et al., 2012; Hairunnizam et al., 2009; Hairunnizam \& Radiah, 2010; Patmawati, 2008; Azman et al., 2012) dan faktor-faktor yang menentukan kejayaan institusi zakat (Abdul Rahman, 2007). Sehingga kini masih belum terdapat kajian berkaitan pelaporan prestasi institusi zakat terutamanya kajian tentang maklumat yang diperlukan oleh pemegang kepentingan untuk dilaporkan oleh institusi zakat. Oleh itu, objektif kajian ini adalah untuk mengkaji keperluan pemegang kepentingan institusi zakat terhadap maklumat yang perlu didedahkan dalam pelaporan prestasi institusi berkenaan dan tahap kepentingan pendedahan item maklumat tersebut. 
IJMS 23 (2), 97-124 (2016)

\section{Sorotan Karya}

Zakat memainkan peranan yang sangat besar di dalam masyarakat Islam sebagai penyucian diri, harta dan masyarakat (Qardawi, 2007). Objektif zakat adalah untuk menegakkan keadilan ekonomi dan sosial iaitu menyumbang kepada pembasmian kemiskinan dan penyelesaian kepada masalah sosial (Norazlina \& Abdul Rahim, 2011; Patmawati, 2008; Qardhawi, 2007). Bagi mencapai objektif ini, institusi zakat ditubuhkan sebagai institusi awam yang bertanggungjawab untuk mengutip dan mengagih zakat secara cekap serta menjadi perantara antara pembayar dan penerima zakat (Syawal \& Hassan 2007). Di Malaysia, zakat ditadbir oleh Majlis Agama Islam Negeri (MAIN) kecuali bagi negeri Kedah yang diuruskan oleh Jabatan Zakat Negeri Kedah.

Pelaporan prestasi dianggap sebagai sebahagian daripada tuntutan akauntabiliti awam. Pelaporan prestasi digunakan untuk menyalurkan maklumat prestasi yang menyeluruh kepada pemegang kepentingan berdasarkan tiga parameter iaitu sasaran yang telah ditetapkan oleh pihak pengurusan atau pemegang kepentingan; prestasi masa lalu dengan menggunakan analisis tren untuk mengkaji sama ada prestasi adalah pada tren menaik atau menurun; dan penanda aras pada industri (Australian National Audit Office 2004; Cohen \& Karatzimas 2014; Connolly \& Hyndman 2003).

Sebagai institusi awam, institusi zakat perlu mengkomunikasikan aktivitinya kepada pihak awam secara amnya dan pemegang kepentingan secara khusus dan medium komunikasi yang boleh digunakan adalah pelaporan prestasi. Pelaporan prestasi yang dikeluarkan kepada pihak awam adalah penting dan merupakan satu cara untuk memastikan kerajaan bertanggungjawab dan telus (Grosso \& Ryzin, 2011). Dengan adanya pelaporan prestasi, pemegang kepentingan terutamanya pihak awam akan merasa lebih yakin dan dihargai serta dapat mengetahui sama ada wang awam yang diamanahkan diuruskan dengan baik dan sempurna di samping membuat perbandingan serta penilaian terhadap program dan aktiviti organisasi yang dipertanggungjawabkan (Engku Ismail, 2006). Pelaporan prestasi adalah bertujuan untuk menjelaskan akauntabiliti organisasi kepada pemegang kepentingannya dan boleh dijadikan sebagai alat pembuatan keputusan oleh pemegang kepentingan sesebuah agensi sektor awam (IFAC, 2011; Hyndman \& Anderson, 1995). 


\section{Item Maklumat Pelaporan Prestasi dan Keperluan Pemegang Kepentingan.}

International Federal of Accountants (IFAC) melalui kertas konsultasinya pada Oktober 2011 mencadangkan agensi sektor awam perlu menyediakan maklumat berkaitan prestasi perkhidmatan di dalam laporan kewangannya. Laporan kewangan agensi sektor awam perlu mengandungi maklumat kewangan dan bukan kewangan, kuantitatif dan kualitatif mengenai pencapaian objektif kewangan dan penyampaian perkhidmatan dalam tempoh laporan semasa dan sebelumnya, dan aktiviti penyampaian perkhidmatan masa hadapan yang dijangka dan keperluan sumber. Pelaporan prestasi perkhidmatan perlu mengandungi objektif perkhidmatan, petunjuk prestasi iaitu input, output, keberhasilan, petunjuk prestasi dan petunjuk keberkesanan.

Maklumat pelaporan prestasi bukan hanya mengandungi maklumat kewangan tetapi juga maklumat bukan kewangan dalam mengenal pasti penanda aras atau sasaran entiti, termasuk maklumat prestasi yang dibentangkan di dalam laporan bajet, rancangan masa depan dan laporan mengenai prestasi program yang dijalankan (IFAC 1996). Oleh itu maklumat prestasi ditakrifkan sebagai maklumat sistematik yang menggambarkan output dan keberhasilan program awam dan organisasi - sama ada bertujuan atau sebaliknya - dijana oleh sistem dan proses-proses yang bertujuan untuk menghasilkan maklumat tersebut (Pollitt, 2006). Maklumat prestasi boleh diberikan dalam bentuk data prestasi kewangan (maklumat kuantitatif) dan data prestasi bukan kewangan (maklumat kualitatif). Kedua-dua maklumat kewangan dan bukan kewangan adalah penting dalam menilai prestasi sektor awam (Norida, 2010).

Maklumat prestasi diperlukan untuk menetapkan sasaran dalam kontrak pengurusan, memberi tumpuan kepada kecekapan, untuk membandingkan prestasi sebenar dan sasaran dan untuk meningkatkan output (Jansen, 2008). Ini termasuk maklumat bagaimana sumber diperoleh, bagaimana sumber-sumber digunakan dalam pengeluaran barangan dan perkhidmatan, bagaimana barangan dan perkhidmatan memenuhi piawaian, bagaimana program mencapai objektif yang ditetapkan dan bagaimana pihak awam berpuas hati dengan perkhidmatan yang disediakan kerajaan. Maklumat seperti ini adalah penting untuk kawalan yang sesuai, perancangan dan tujuan akauntabiliti (Reid \& Adibe, 1976; Grosso \& Ryzin, 2011; Suhaiza \& Nur Barizah, 2011). Grosso dan 
Ryzin (2011) menyatakan pelaporan prestasi yang utama adalah melalui laporan tahunan dan merupakan medium utama untuk menjelaskan akauntabiliti organisasi sektor awam kepada pemegang kepentingannya.

Banyak kajian lepas membincangkan keperluan maklumat berdasarkan kehendak pemegang kepentingan dan keperluan ini perlu dipenuhi untuk mendedahkan maklumat dan aktiviti organisasi (Hooks et al. 2012; Tooley et al. 2010; Daniels dan Daniels 1991; Stöetzer dan Hilgers 2011; CICA 2011 dan Zainon et al. 2013). Hooks et al. (2012) dan Tooley et al. (2010) mengkaji item maklumat prestasi yang diperlukan oleh pemegang kepentingan Pihak Berkuasa Tempatan boleh dikategorikan kepada (1) Gambaran keseluruhan dan operasi ; (2) Prestasi bukan kewangan; (3) Penyata kewangan; (4) Maklumat kewangan di luar daripada penyata kewangan dan (5) Maklumat yang berkaitan masa hadapan. Daniels dan Daniels (1991) mengenal pasti empat jenis maklumat yang diperlukan oleh pemegang kepentingan iaitu (1) Maklumat mengenai pematuhan; (2) Maklumat mengenai kedudukan kewangan semasa dan jangka masa depan; (3) Maklumat mengenai prestasi operasi dan (4) Maklumat mengenai kecekapan dan keberkesanan.

Menurut Stöetzer dan Hilgers (2011) pelaporan prestasi boleh membantu memenuhi permintaan semasa pemegang kepentingan bagi penilaian prestasi, menjelaskan akauntabiliti dan meningkatkan dana dalam organisasi bukan keuntungan, Setiap pemegang kepentingan mempunyai keperluan maklumat yang tertentu dan berlainan. Penderma yang menyokong organisasi bukan berasaskan keuntungan bukan hanya menumpukan kepada maklumat kewangan semata-mata tetapi juga mementingkan maklumat bukan kewangan terutama maklumat prestasi perkhidmatan seperti maklumat tentang input dan output dan keberkesanan sesuatu program yang dijalankan. Stöetzer dan Hilgers (2011) menyatakan pemegang kepentingan organisasi bukan berasaskan keuntungan memerlukan maklumat berikut:

- Maklumat keterangan pematuhan- Maklumat berkaitan falsafah organisasi bukan keuntungan tersebut, misi organisasi, maklumat kepatuhan nilai dan lain-lain.

- Jenis aktiviti- Maklumat berkaitan aktiviti yang dijalankan oleh organisasi.

- $\quad$ Skop kerja sukarela- Maklumat berkaitan kerja-kerja sukarela yang telah dijalankan

- Kelebihan pelanggan- Maklumat berkaitan manfaat yang diterima oleh penerima. 
- Kelebihan kepada sukarelawan- maklumat perihal insentif kewangan. Keperluan ekonomi untuk kerja-kerja sukarelamaklumat berkaitan aset bersih, kedudukan kewangan dan keputusan operasi (lembaran imbangan, penyata pendapatan dan penyata aliran tunai).

- $\quad$ Prestasi - penerangan mengenai objektif dan tahap pencapaian sasaran berkaitan objektif yang ditentukan dalam tempoh dan sebelumnya. Penerangan mengenai perbelanjaan yang dibuat untuk mencapai objektif juga perlu didedahkan.

Canadian Institute of Chartered Accountants (CICA 2011) pula menyatakan maklumat kewangan adalah satu elemen laporan tahunan. Walau bagaimanapun, penyata kewangan semata-mata tidak cukup untuk mengkomunikasikan semua maklumat mengenai organisasi yang diperlukan oleh pemegang berkepentingan, terutamanya dalam sektor bukan untuk keuntungan. Bagi kebanyakan organisasi bukan untuk keuntungan, penyata kewangan hanya merangkumi sebahagian kecil maklumat mengenai prestasi organisasi. Contoh elemen-elemen utama yang tidak terdapat di dalam penyata kewangan adalah sumbangan sukarelawan dan kesannya kepada masyarakat. Maklumat ini tidak mudah untuk dijelaskan dari segi kewangan, tetapi mudah difahami melalui maklumat prestasi organisasi. Melalui laporan naratif yang disertakan bersama penyata kewangan sesebuah organisasi berpeluang untuk menjelaskan maklumat kewangan dan mengemukakan langkah-langkah bukan kewangan yang penting untuk menunjukkan prestasi organisasi.

CICA (2011) mencadangkan laporan tahunan organisasi bukan berasaskan keuntungan perlu mengandungi maklumat seperti (1) Maklumat berkaitan tujuan organisasi ditubuhkan; (2) Maklumat berkaitan misi dan visi organisasi (3) Strategi; (4) Objektif dan prestasi; (5) Risiko dan peluang dan (6) Maklumat kewangan dan bukan kewangan; (7) Kaedah pengumpulan dana dan hasil; (8) Prospek masa hadapan; (9) Struktur organisasi dan kepimpinan dan (10) Tadbir Urus.

Sebagai kesimpulan, kajian lepas berkaitan pemegang kepentingan atau keperluan maklumat telah mengiktiraf kepentingan keperluan pemegang kepentingan yang perlu dipertimbangkan dalam penyampaian maklumat yang relevan kepada mereka. Perhatian kepada pemegang kepentingan adalah penting kerana pencapaian 
organisasi awam adalah bergantung kepada apa yang dapat memuaskan kehendak pemegang kepentingan yang anggap sebagai amat bernilai (Norida 2010).

\section{Maklumat pelaporan prestasi di Malaysia}

Di Malaysia peranan maklumat pelaporan prestasi turut diberikan perhatian. (Pekeliling Perbendahara Bil.15 Tahun 1994 telah dikeluarkan kepada semua Badan Berkanun Persekutuan yang merupakan garis panduan untuk penyediaan dan pembentangan Laporan Tahunan. Pekeliling ini telah dikemas kini melalui Pekeliling Perbendaharaan Bil. 4 Tahun 2007 yang menggantikan pekeliling tersebut. Melalui pekeliling ini Kementerian Kewangan telah menetapkan perkara-perkara yang perlu didedahkan di dalam Laporan Tahunan Badan Berkanun Persekutuan yang terdiri daripada maklumat kewangan dan bukan kewangan. Di dalam konteks institusi zakat, hanya Majlis Agama Islam Wilayah Persekutuan sahaja termasuk di dalam kategori Badan Berkanun Persekutuan dan tertakluk kepada pekeliling berkenaan manakala 13 Institusi Zakat yang lain tidak tertakluk kepada pekeliling ini kerana dikategorikan sebagai agensi di bawah sektor negeri.

Di dalam menyalurkan maklumat kepada pemegang kepentingan institusi zakat tidak hanya perlu menyediakan penyata kewangan beraudit sahaja tetapi perlu mendedahkan keseluruhan maklumat kewangan dan bukan kewangan kepada pemegang kepentingan khasnya pembayar zakat. Ini penting kerana ia boleh menghindarkan tuduhan penyelewengan dan ketidakpuasan pemegang kepentingan terhadap institusi zakat. Melalui pelaporan prestasi masalah kekurangan maklumat mengenai prestasi institusi zakat dapat dikurangkan. Melalui Pekeliling Perbendaharaan Bil 42007 maklumat yang perlu didedahkan di dalam laporan tahunan adalah seperti berikut:

- Maklumat korporat

- Latar belakang organisasi

- Laporan Pengerusi

- Laporan ke atas bantuan daripada Kerajaan

- Analisis prestasi kewangan

- Analisis prestasi bukan kewangan

- $\quad$ Penyata Kewangan yang telah diaudit

Kajian Suhaiza dan Nur Barizah (2011) mengenal pasti maklumat prestasi yang didedahkan di dalam laporan tahunan dan laman web 
universiti awam di Malaysia berdasarkan keperluan Pekeliling Bil 4 Tahun 2007 dan sebahagian item maklumat akauntabiliti yang dicadangkan oleh Coy et al. (1993) iaitu pendedahan maklumat akauntabiliti diubahsuai (MAD). Melalui kajian ini di dapati universiti awam tidak mendedahkan kesemua maklumat yang perlu didedahkan berdasarkan di dalam Pekeliling Bil 4 Tahun 2007.

Sheila $\mathrm{Nu} \mathrm{Nu}$ dan Salman (2014) pula mencadangkan maklumat kewangan yang perlu didedahkan di dalam laporan tahunan institusi zakat di Malaysia berdasarkan pandangan pentadbir zakat. Membahagikan maklumat kewangan kepada 7 bahagian utama iaitu (1) pendedahan berkaitan polisi perakaunan yang digunakan; (2) perubahan polisi dan lembaga pemegang amanah institusi zakat; (3) pendedahan berkaitan risiko pengurusan; (4) pendedahan berkaitan sistem kawalan dalaman; (5) pendedahan berkaitan perkara penting yang perlu diberi perhatian; (6) pendedahan berkaitan pungutan zakat; (7) pendedahan berkaitan pengagihan zakat dan penyata aliran tunai.

Sebagai kesimpulan, kajian lepas berkaitan pemegang kepentingan atau keperluan maklumat telah mengiktiraf kepentingan keperluan pemegang kepentingan yang perlu dipertimbangkan dalam penyampaian maklumat yang relevan kepada mereka. Perhatian kepada pemegang kepentingan adalah penting kerana pencapaian organisasi awam adalah bergantung kepada apa yang dapat memuaskan kehendak pemegang kepentingan yang anggap sebagai amat bernilai (Norida 2010).

Kajian lepas telah mengiktiraf pelaporan prestasi sebagai medium untuk menjelaskan akauntabiliti kepada pemegang kepentingan dan membincangkan item maklumat yang perlu di dedahkan di dalam pelaporan prestasi (Tooley et al., 2010; Hooks et al. 2012; Hynman dan Anderson,1995; Shiela $\mathrm{Nu} \mathrm{Nu}$ dan Salman 2014; Lapsley 1992; Stoetzer dan Dennis 2011 dan Norida 2010) dan dari badan profesional seperti IFAC dan CICA (2011). Kajian-kajian ini mencadangkan maklumat pelaporan prestasi yang didedahkan perlu mengandungi maklumat kewangan dan bukan kewangan. Walau bagaimanapun dalam konteks institusi zakat, belum terdapat kajian terperinci berkaitan item maklumat pelaporan prestasi mengikut keperluan pemegang kepentingannya. Bagi meningkatkan keyakinan pemegang kepentingan dan menjelaskan akauntabiliti institusi zakat, 
satu kajian mengenai keperluan pemegang kepentingan terhadap pendedahan maklumat di dalam pelaporan prestasi institusi zakat adalah diperlukan.

\section{Kerangka Kerja Kajian}

Teori yang mendasari kajian ini adalah teori akauntabiliti dan teori pemegang kepentingan. Gray dan Jenkins (1993) dan INTAN (1994) mendefinisikan akauntabiliti sebagai kewajipan individu/organisasi yang diamanahkan dengan tanggungjawab untuk melaksanakan tanggungjawab tersebut dan menjelaskan tindakan mereka kepada individu/ organisasi yang memberi tanggungjawab. Coy et al. (2001) dan Hyndman dan Anderson (1995) menyatakan akauntabiliti boleh dijelaskan melalui pelaporan maklumat yang menyeluruh tentang keadaan, prestasi, aktiviti dan kemajuan kepada mereka yang mempunyai kepentingan sosial, ekonomi dan politik iaitu terdiri daripada maklumat kewangan dan maklumat bukan kewangan.

Daripada perspektif Islam, Hameed (2000) mengkelaskan akauntabiliti kepada dwi akauntabiliti iaitu akauntabiliti utama adalah kepada Allah (s.w.t) manakala akauntabiliti kedua adalah kepada individu/ organisasi yang memberikan tanggungjawab. Dalam konteks kajian ini, konsep akauntabiliti kedua adalah difokuskan. Untuk menjelaskan akauntabiliti kedua ini, organisasi perlu mengenalpasti, mengukur dan melaporkan semua aktiviti kepada pemegang kepentingan seperti objektif organisasi, kesaksamaan dalam pengagihan kekayaan di kalangan pemegang kepentingan dan membuat penilaian terhadap prestasi. Dalam konteks institusi zakat, Murtala (2008) membahagikan akauntabiliti institusi zakat kepada akauntabiliti kepada Allah (s.w.t) dan akauntabiliti kepada pembayar dan penerima zakat sebagai pemegang kepentingan utama institusi zakat iaitu organisasi yang diberi tanggungjawab untuk bertindak dan menjelaskan tindakan mereka kepada pembayar dan penerima zakat sebagai individu yang memberi tanggungjawab.

Teori akauntabiliti menerangkan tentang akauntabiliti kepada siapa, akauntabiliti untuk apa dan bagaimana akauntabiliti itu boleh dijelaskan. Akauntabiliti kepada siapa adalah merujuk kepada pihak pemegang kepentingan iaitu pihak yang perlu diberi penjelasan (Neale dan Anderson, 2000). Akauntabiliti untuk apa merujuk kepada skop akauntabiliti yang perlu dijelaskan iaitu termasuk 
skop kewangan dan iaitu akauntabiliti kewangan atau fiscal dan skop prestasi (Engku Ismail, 2006; Theresa Dunnes, 2013; IFAC, 2011 dan Tooley et al., 2010). Bagaimana akauntabiliti boleh dijelaskan adalah merujuk kepada medium yang digunakan untuk menjelaskan akauntabiliti kepada pihak pemegang kepentingan. Bagi tujuan ini, laporan tahunan merupakan dokumen utama dalam pelaporan prestasi sesebuah organisasi (Hoque, 2008).

Teori pemegang kepentingan menjelaskan siapakah yang dimaksudkan sebagai pemegang kepentingan. Teori ini telah diperkenalkan oleh Freeman (1984) yang mendefinisikan pemegang kepentingan dalam sesebuah organisasi sebagai pihak, kumpulan atau individu yang boleh mempengaruhi atau dipengaruhi bagi mencapai objektif organisasi. Pemegang kepentingan boleh dikelaskan kepada pemegang kepentingan dalaman (pengurus, kakitangan organisasi) dan luaran (pengguna, media, pesaing dan kerajaan) yang mana keperluan maklumat mereka perlu dipenuhi oleh organisasi berkenaan. Teori pemegang kepentingan juga menjelaskan bahawa keperluan pemegang kepentingan terutamanya pemegang kepentingan utama perlu dipenuhi oleh organisasi yang melapor. Dalam konteks institusi zakat, pemegang kepentingannya adalah terdiri daripada pembayar zakat, pentadbir zakat (pekerja dan pihak pengurusan/ lembaga pemegang amanah), masyarakat, kerajaan dan lapan golongan penerima zakat (Hussain, 2001). Berdasarkan teori akauntabiliti dan teori pemegang kepentingan, model kajian telah dibentuk seperti Rajah 1.

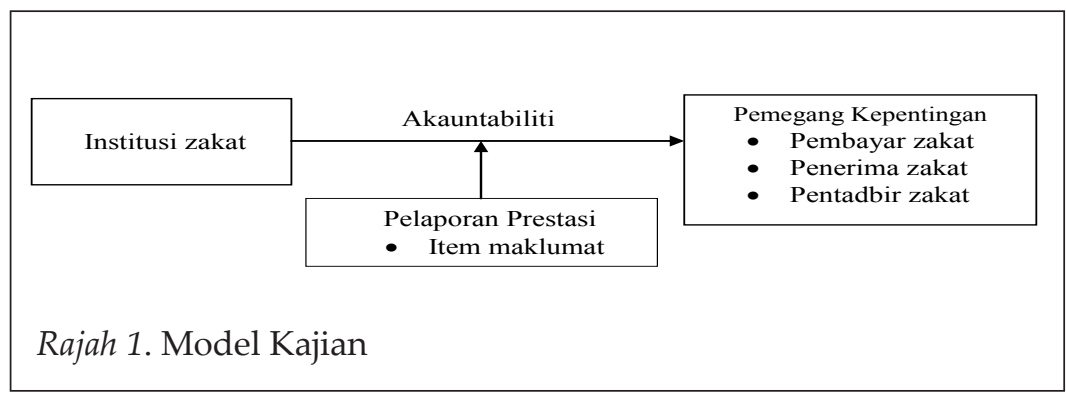

Berdasarkan Rajah 1, akauntabiliti institusi zakat (selepas akauntabiliti utama kepada Allah) adalah akauntabiliti kepada pihak pemegang kepentingannya terutamanya pembayar zakat, penerima zakat dan pentadbir zakat. Selari dengan teori pemegang kepentingan, 
keperluan pihak pemegang kepentingan (dalam konteks kajian ini adalah keperluan maklumat prestasi) perlu dipenuhi.

Bagi tujuan ini, pelaporan prestasi memainkan peranan penting dalam menjelaskan akauntabiliti institusi zakat kepada pemegang kepentingannya. Melalui pelaporan prestasi, institusi zakat boleh menjelaskan segala keraguan dan ketidakpastian pembayar zakat dengan mendedahkan maklumat keseluruhan aktiviti, prestasi, sasaran dan kemajuan aktiviti dan yang paling penting kemanakah wang zakat disalur dan dibelanjakan.

\section{Metodologi Kajian}

Kajian ini menggunakan pendekatan kuantitatif. Kaedah tinjauan menggunakan soal selidik dilakukan terhadap tiga kumpulan pemegang kepentingan iaitu pembayar zakat, penerima zakat dan pentadbir zakat. Ketiga-tiga pihak ini dipilih kerana mereka merupakan pemegang kepentingan utama institusi zakat (Hussain, 2001 dan Murtala, 2008). Melalui kaedah ini, responden diminta memberikan pandangan mereka terhadap keperluan maklumat yang perlu didedahkan dalam laporan prestasi institusi zakat dan kepentingan pendedahan maklumat-maklumat tersebut. Mereka juga boleh mencadangkan maklumat tambahan yang diperlukan di dalam pelaporan prestasi. Populasi kajian ialah pembayar dan penerima zakat yang mendaftar di institusi zakat serta pentadbir zakat di setiap negeri. Institusi zakat di Wilayah Persekutuan, Selangor, Terengganu dan Perak didapati mempunyai laporan tahunan. Kajian ini mengandaikan pembayar dan penerima zakat di negeri-negeri tersebut mempunyai gambaran awal tentang pelaporan prestasi. Manakala bagi pentadbir zakat, populasi mereka diperolehi daripada kesemua 14 institusi zakat di Malaysia iaitu pentadbir zakat dari bahagian kewangan, audit, pengutipan zakat dan agihan zakat. Jadual Penentuan Saiz Sampel Krejcie dan Morgan (1970) digunakan untuk menentukan saiz sampel dan pemilihan sampel dibuat secara persampelan bertujuan.

Dalam menentukan item-item maklumat pelaporan prestasi yang dinyatakan dalam soal selidik, sorotan meluas telah dibuat terhadap karya lepas, pekeliling kerajaan dan cadangan daripada badan professional. Item maklumat terdiri maklumat bukan kewangan dan kewangan. Pendapat responden digunakan bagi mengetahui perbezaan pandangan terhadap tahap kepentingan item maklumat didedahkan di dalam pelaporan prestasi kepada responden. Jadual 
IJMS 23 (2), 97-124 (2016)

1 menunjukkan item maklumat, sumber pengukuran dan skala yang digunakan.

\section{Jadual 1}

\section{Pengukuran Pemboleh ubah.}

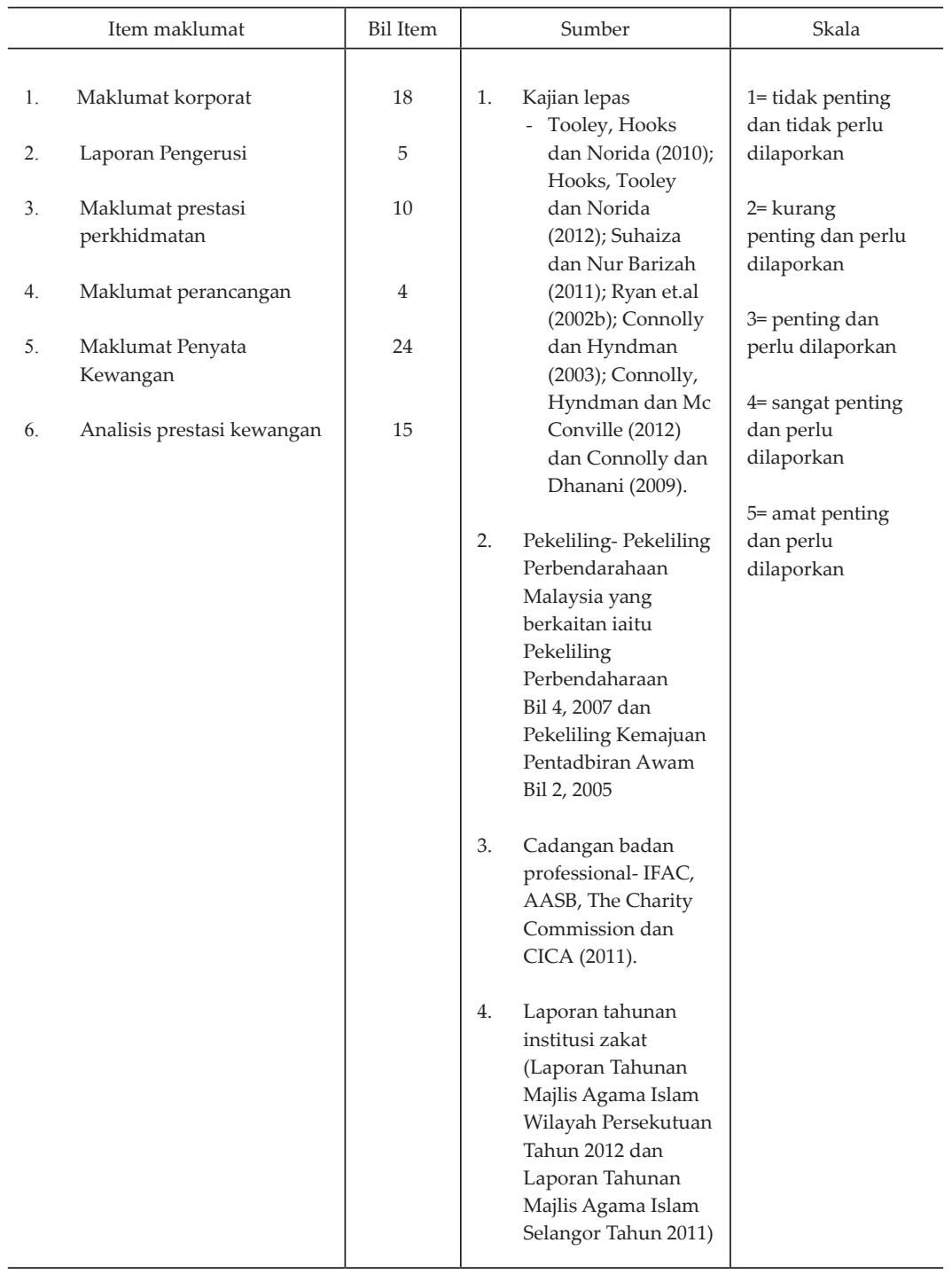


IJMS 23 (2), 97-124 (2016)

\section{Hasil Kajian Dan Perbincangan}

Sejumlah 1,000 soal selidik yang diedarkan kepada penerima, pembayar dan pentadbir zakat. Jadual 2 menunjukkan kadar maklum balas yang diperoleh iaitu sebanyak 386 (38.6\%) telah dikembalikan dan hanya $323(32.3 \%)$ sahaja yang dapat digunakan di dalam kajian ini. Sebanyak 63 (6.3\%) tidak dapat digunakan kerana tidak dijawab dengan lengkap. Kadar maklum balas 32.3\% adalah dianggap baik jika dibandingkan dengan kajian-kajian lepas (Tooley et al.2010; Grosso dan Ryzin, 2011 dan Shiela Nu Nu dan Salman, 2014).

Jadual 2

Kadar Maklum Balas

\begin{tabular}{lcccc}
\hline $\begin{array}{l}\text { Pemegang } \\
\text { Kepentingan }\end{array}$ & $\begin{array}{l}\text { Bilangan } \\
\text { soal selidik } \\
\text { yang telah } \\
\text { diedarkan }\end{array}$ & $\begin{array}{l}\text { Bilangan soal } \\
\text { selidik yang di } \\
\text { peroleh semula }\end{array}$ & $\begin{array}{l}\text { Soal selidik yang } \\
\text { digunakan }\end{array}$ & \\
\hline Pembayar Zakat & 384 & 140 & 131 & 13.1 \\
Penerima Zakat & 384 & 128 & 79 & 7.9 \\
Pentadbir Zakat & 232 & 115 & 113 & 11.3 \\
Jumlah & 1,000 & 383 & 323 & 32.3 \\
\hline
\end{tabular}

Seluruh responden kajian adalah pemegang kepentingan institusi zakat iaitu kumpulan pembayar, penerima dan pentadbir zakat. Responden kajian diwakili oleh latar belakang yang menyeluruh daripada aspek umur, jantima, kelayakan akademik dan pekerjaan. Jadual 3 menunjukkan profil demografi responden kajian ini.

Jadual 3

Profil Demografi Responden

\begin{tabular}{llrr}
\hline Ciri-ciri & Kategori & Bilangan & Peratusan (\%) \\
\hline Jantina: & Lelaki & 116 & 35.9 \\
& Perempuan & 207 & 64.1 \\
& Jumlah & 323 & 100 \\
\hline
\end{tabular}

(sambungan) 
IJMS 23 (2), 97-124 (2016)

\begin{tabular}{|c|c|c|c|}
\hline Ciri-ciri & Kategori & Bilangan & Peratusan $(\%)$ \\
\hline \multirow[t]{5}{*}{ Umur: } & 30 tahun ke bawah & 159 & 49.2 \\
\hline & 31-40 tahun & 102 & 31.6 \\
\hline & 41-50 tahun & 48 & 14.9 \\
\hline & 51 tahun ke atas & 14 & 4.3 \\
\hline & Jumlah & 323 & 100 \\
\hline Kelayakan & Doktor Falsafah & 2 & 0.6 \\
\hline \multirow[t]{8}{*}{ Akademik: } & Ijazah Sarjana & 23 & 7.1 \\
\hline & Ijazah Sarjana & 129 & 39.9 \\
\hline & Muda & 73 & 22.6 \\
\hline & Diploma & 46 & 14.2 \\
\hline & STPM & 42 & 13 \\
\hline & SPM & 8 & 2.5 \\
\hline & Lain-lain & & \\
\hline & Jumlah & 323 & 100 \\
\hline \multirow[t]{9}{*}{ Pekerjaan: } & Pengurusan Atasan & 10 & 3.1 \\
\hline & Profesional & 73 & 22.6 \\
\hline & Pentadbiran dan & 127 & 39.3 \\
\hline & Pengurusan & 45 & 13.9 \\
\hline & Perkeranian & 25 & 7.7 \\
\hline & Tidak bekerja & 38 & 11.8 \\
\hline & Pelajar & 5 & 1.5 \\
\hline & Lain-lain & & \\
\hline & Jumlah & 323 & 100 \\
\hline
\end{tabular}

Keputusan analisis deskriptif dan analisis Kruskal-Walis ditunjukkan di dalam Jadual 4. Analisis deskriptif dari segi nilai minimum, maksimum, min dan sisihan piawai telah dilaksanakan bagi mengetahui pandangan pemegang kepentingan terhadap tahap kepentingan pendedahan item maklumat pelaporan prestasi. Analisis Kruskal-Wallis adalah kaedah analisis bukan parametrik untuk menguji perbezaan sehala di antara kumpulan varian. Ia membenarkan perbandingan dibuat ke atas lebih daripada 2 kumpulan atau kategori. Kaedahnya ialah skor akan di tukar kepada susunan mengikut susunan terendah sehingga yang tertinggi dan seterusnya purata pangkatan bagi setiap kumpulan akan di bandingkan (Chua Yan Piaw 2008).

Jadual 4 menunjukkan, bagi maklumat bukan kewangan, responden sangat mementingkan maklumat perancangan dan maklumat 
prestasi perkhidmatan. Ini selaras dengan kehendak Pekeliling Perbendaharaan Bil 4, 2007, cadangan badan professional- IFAC, AASB dan The Charity Commission. Jika dilihat daripada keperluan setiap pemegang kepentingan institusi zakat, skor min adalah berbeza. Pembayar zakat lebih mengutamakan item maklumat laporan Ketua Audit Negara, maklumat penyata pendapatan dan perbelanjaan, maklumat perancangan dan maklumt prestasi (skor min melebihi 4). Manakala penerima zakat lebih mementingkan maklumat perancangan dan maklumat penyata pendapatan dan perbelanjaan. Pentadbir zakat pula lebih mementingkan maklumat Sijil dan laporan Ketua Audit Negara, maklumat penyata pendapatan dan perbelanjaan, maklumat perancangan, maklumat lembaran imbangan, maklumat prestasi perkhidmatan dan maklumat nota kepada penyata kewangan.

Jadual 4

\section{Analisis Deskriptif}

\begin{tabular}{|c|c|c|c|c|c|c|c|c|c|}
\hline \multirow[t]{2}{*}{ Item Maklumat } & \multirow[t]{2}{*}{ Bil } & \multirow[t]{2}{*}{$\mathrm{Mn}$} & \multirow[t]{2}{*}{$\mathrm{Mx}$} & \multirow[t]{2}{*}{ S.P } & \multicolumn{4}{|c|}{ Skor Min } & \multirow{2}{*}{$\begin{array}{l}\text { Nilai } \\
\mathrm{P}\end{array}$} \\
\hline & & & & & K & B & $\mathrm{T}$ & $\mathrm{TD}$ & \\
\hline \multicolumn{10}{|l|}{$\begin{array}{l}\text { Maklumat Bukan } \\
\text { Kewangan }\end{array}$} \\
\hline Maklumat Korporat & 18 & 1 & 5 & 0.700 & 3.86 & 3.92 & 3.77 & 3.86 & 0.779 \\
\hline Laporan Pengerusi & 5 & 1 & 5 & 0.743 & 3.91 & 3.98 & 3.73 & 3.97 & 0.366 \\
\hline $\begin{array}{l}\text { Maklumat Prestasi } \\
\text { Perkhidmatan }\end{array}$ & 10 & 1 & 5 & 0.694 & 4.04 & 4.18 & 3.79 & 4.04 & $0.005^{*}$ \\
\hline Maklumat Perancangan & 4 & 1 & 5 & 0.797 & 4.16 & 4.19 & 4.14 & 4.15 & 0.829 \\
\hline \multicolumn{10}{|l|}{ Maklumat Kewangan } \\
\hline \multicolumn{10}{|l|}{ Penyata Kewangan: } \\
\hline $\begin{array}{l}\text { Sijil dan Laporan Ketua } \\
\text { Audit Negara }\end{array}$ & 1 & 1 & 5 & 0.922 & 4.37 & 4.64 & 3.90 & 4.40 & $0.000^{*}$ \\
\hline Lembaran Imbangan & 6 & 1 & 5 & 0.786 & 3.97 & 3.99 & 3.78 & 4.09 & 0.154 \\
\hline $\begin{array}{l}\text { Penyata Pendapatan dan } \\
\text { Perbelanjaan }\end{array}$ & 6 & 1 & 5 & 0.750 & 4.30 & 4.50 & 4.05 & 4.25 & $0.001^{*}$ \\
\hline $\begin{array}{l}\text { Penyata Perubahan } \\
\text { Ekuiti }\end{array}$ & 2 & 1 & 5 & 0.896 & 3.73 & 3.70 & 3.59 & 3.83 & 0.455 \\
\hline Penyata Aliran Tunai & 4 & 1 & 6 & 0.860 & 3.90 & 3.99 & 3.63 & 3.99 & 0.051 \\
\hline $\begin{array}{l}\text { Nota Kepada Penyata } \\
\text { Kewangan }\end{array}$ & 5 & 1 & 5 & 0.854 & 3.95 & 4.05 & 3.70 & 4.03 & 0.119 \\
\hline
\end{tabular}


IJMS 23 (2), 97-124 (2016)

\begin{tabular}{lccccccccc}
\hline Item Maklumat & Bil & Mn & Mx & S.P & & Skor Min & & $\begin{array}{c}\text { Nilai } \\
\text { P }\end{array}$ \\
\hline & & & & & K & B & T & TD \\
\hline $\begin{array}{l}\text { Analisis Prestasi } \\
\text { Kewangan }\end{array}$ & 11 & 1 & 5 & 0.804 & 3.84 & 3.92 & 3.72 & 3.83 & 0.543 \\
$\begin{array}{l}\text { Nisbah Prestasi } \\
\text { Kewangan }\end{array}$ & 4 & 1 & 5 & 1.194 & 3.52 & 3.58 & 3.47 & 3.50 & 0.738 \\
\hline
\end{tabular}

$\mathrm{Mn}=$ minimum, $\mathrm{Mx}=$ maksimum, $\mathrm{S} . \mathrm{P}=$ sisihan piawai,

$\mathrm{K}=$ Keseluruhan, $\mathrm{B}=$ Pembayar Zakat, $\mathrm{T}=$ Penerima Zakat, TD=Pentadbir Zakat

* terdapat perbezaan yang signifikan di mana nilai $\mathrm{p}<0.05$

Berdasarkan Jadual 4, secara keseluruhannya responden menyatakan tahap kepentingan pendedahan yang tinggi (skor min melebihi 4) kepada maklumat kewangan iaitu maklumat sijil dan laporan Ketua Audit Negara serta maklumat penyata pendapatan dan perbelanjaan. Maklumat sijil dan laporan Ketua Audit Negara boleh dibahagikan kepada empat iaitu sijil tanpa teguran (Penyata Kewangan telah disediakan dan dipersembahkan mengikut piawaian yang diterima pakai, diamalkan secara konsisten, seragam serta pendedahan yang mencukupi), sijil berteguran (perkara material yang boleh menjelaskan kesaksamaan penyata kewangan dari aspek prinsip perakaunan yang digunakan, konsistensi atau had disebabkan kekangan skop pengauditan), sijil bertentangan (penyata kewangan tidak menunjukkan kedudukan yang benar dan saksama atau tidak mematuhi prinsip perakaunan yang diterima umum) dan sijil penafian (kesan yang mungkin timbul daripada kekangan skop pengauditan adalah material dan menyeluruh di mana bukti tidak mencukupi untuk memberi pendapat terhadap penyata kewangan). Oleh kerana responden mementingkan maklumat sijil dan laporan Ketua Audit Negara, ia menunjukkan responden amat mementingkan kualiti penyata kewangan yang didedahkan.

Dapatan kajian ini selari dengan kajian Suhaiza dan Nur Barizah (2011); Hooks et al. (2012) dan Pekeliling Perbendaharaan Bil 4 tahun 2007. Responden juga memberikan skor yang tinggi kepada maklumat di dalam penyata pendapatan dan perbelanjaan iaitu skor min 4.30. Ini menunjukkan maklumat penyata pendapatan dan perbelanjaan adalah amat penting bagi pemegang kepentingan untuk didedahkan di dalam pelaporan prestasi. Penyata Pendapatan mempunyai maklumat secara terperinci mengenai jumlah dan jenis kutipan zakat juga jumlah agihan zakat kepada setiap asnaf. Dapatan 
ini adalah selari dengan kajian lepas yang amat mementingkan pendedahan terperinci maklumat pendapatan dan perbelanjaan organisasi (Tooley et al.,2010; Hooks et al., 2012; Suhaiza dan Nur Barizah ,2011; Connolly dan Hyndman, 2003; Connolly, Hyndman dan Mc Conville, 2012 dan Connolly dan Dhanani, 2009)

Jadual 4 merangkumi analisis Kruskal-Wallis yang menunjukkan terdapat perbezaan signifikan terhadap kepentingan pendedahan maklumat di kalangan kumpulan pemegang kepentingan bagi item maklumat prestasi perkhidmatan, maklumat sijil dan Laporan Ketua Audit Negara dan maklumat penyata pendapatan dan perbelanjaan di mana nilai $\mathrm{p}<0.05$ iaitu jika dilihat dari skor min, penerima zakat kurang mementingkan maklumat tersebut berbanding pembayar dan pentadbir zakat. Secara keseluruhan pemegang kepentingan mendapati kesemua maklumat-maklumat kewangan dan bukan kewangan penting untuk didedahkan di dalam pelaporan prestasi di mana skor min melebihi 3. Daripada keseluruhan item maklumat, maklumat Sijil dan laporan Ketua Audit Negara, penyata pendapatan dan perbelanjaan, maklumat prestasi perkhidmatan dan maklumat perancangan dianggap sangat penting (skor min melebihi 4) untuk didedahkan di dalam pelaporan prestasi. Dapatan ini adalah selari dengan dapatan kajian lepas yang menyokong maklumat prestasi perkhidmatan dan perancangan amat penting untuk didedahkan di dalam pelaporan prestasi bagi menjelaskan akauntabiliti organisasi kepada pemegang kepentingannya (Connolly dan Hyndman, 2003; Connolly, Hyndman dan Mc Conville, 2012; Connolly dan Dhanani, 2009; IFAC, 2011 dan The Charity Commission, 2005).

Analisis Mann Whithney U dilakukan untuk melihat perbezaan yang signifikan antara dua kumpulan pemegang kepentingan terhadap keperluan maklumat keseluruhan dan operasi dan maklumat kewangan. Ia juga dijalankan untuk melihat perbezaan signifikan antara dua kumpulan pemegang kepentingan terhadap kegunaan Laporan Tahunan. Jadual 5 menunjukkan analisis Perbezaan Keperluan Tahap Pendedahan Maklumat Pelaporan Prestasi Di antara Pemegang Kepentingan bagi setiap item maklumat laporan prestasi. Secara keseluruhannya didapati terdapat perbezaan yang signifikan terhadap maklumat korporat, maklumat laporan pengerusi, maklumat prestasi perkhidmatan, maklumat penyata kewangan dan maklumat analisis prestasi kewangan. Manakala maklumat perancangan tiada perbezaan yang signifikan terhadap tahap keperluan pendedahan. 
IJMS 23 (2), 97-124 (2016)

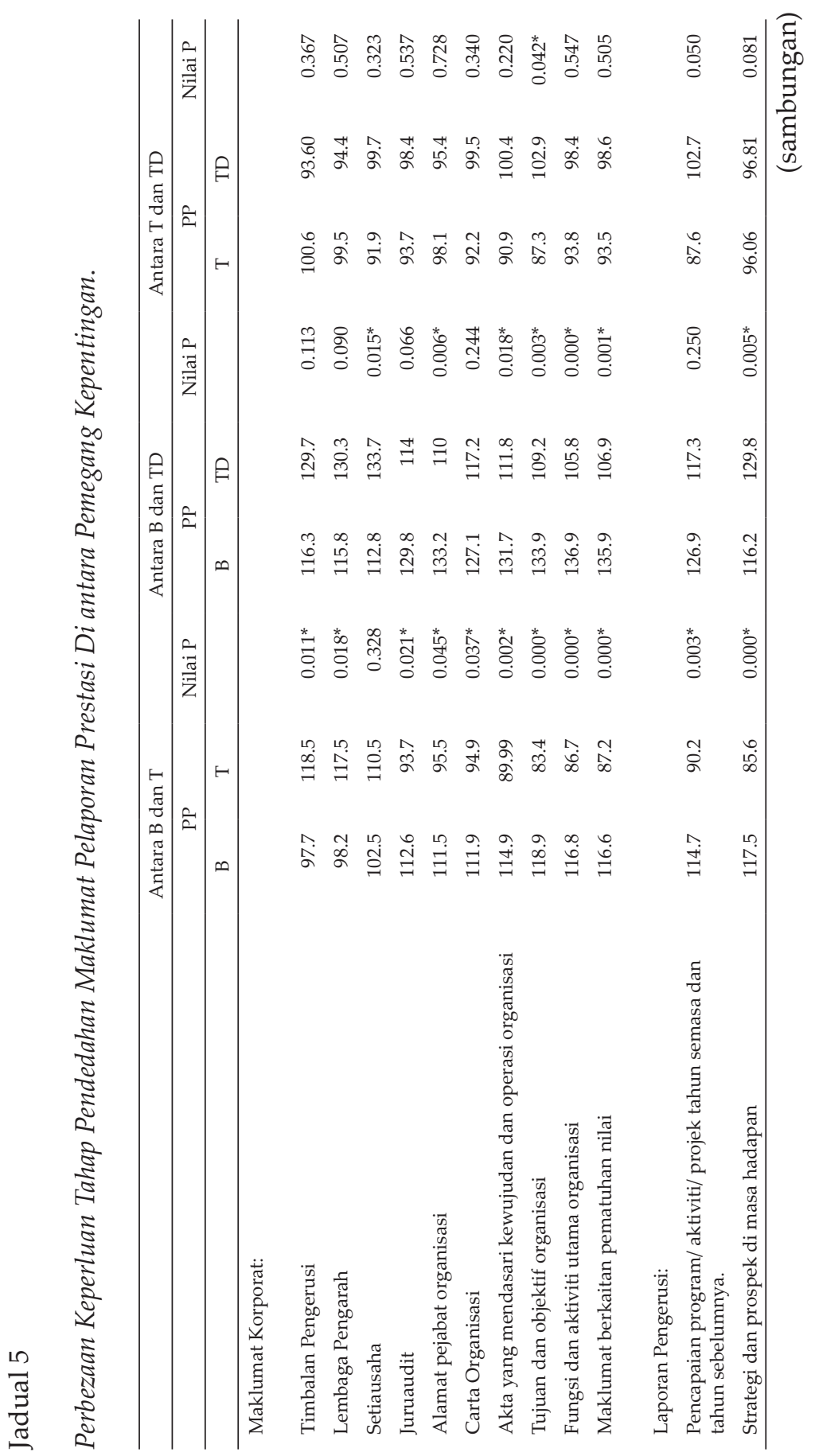


IJMS 23 (2), 97-124 (2016)

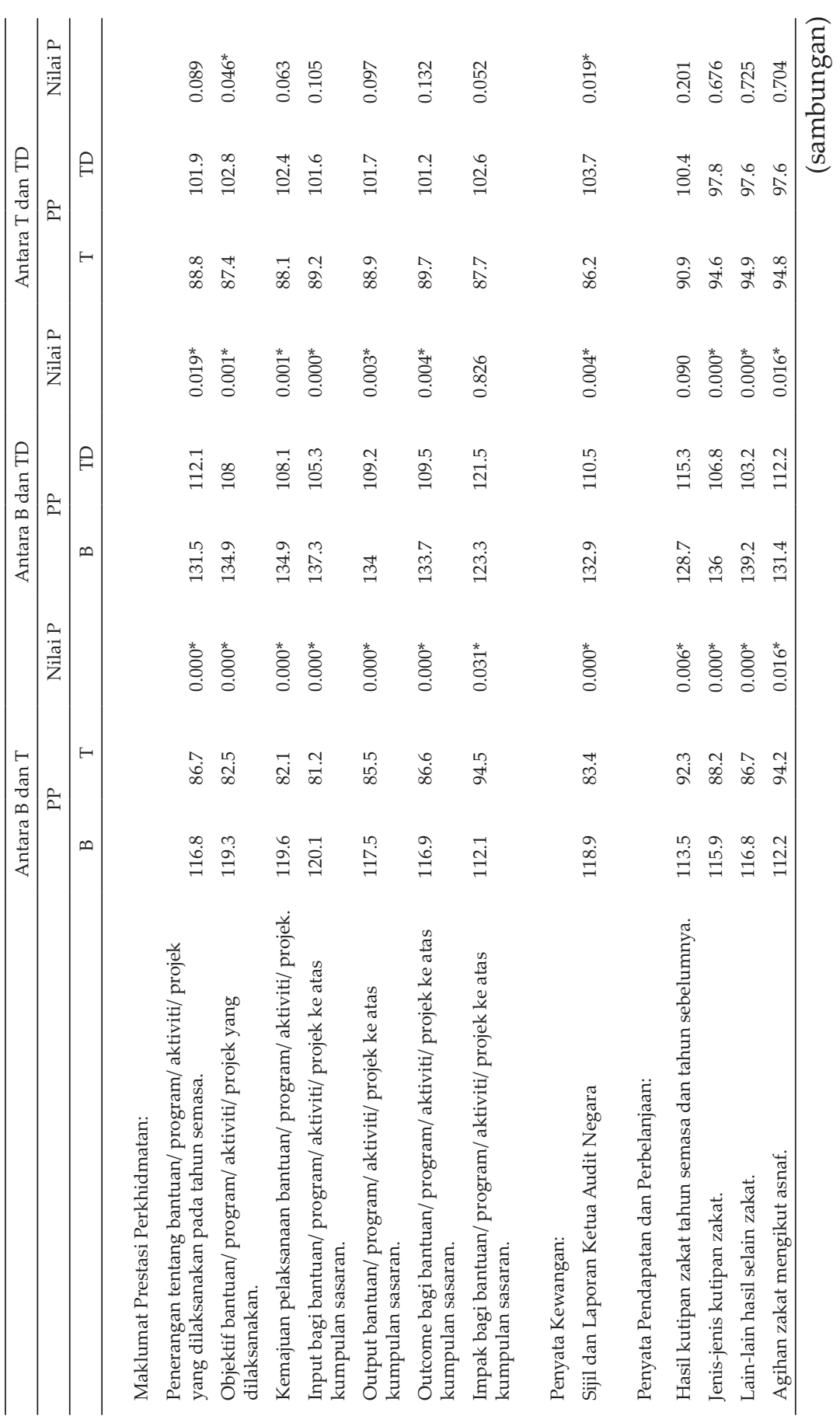


IJMS 23 (2), 97-124 (2016)

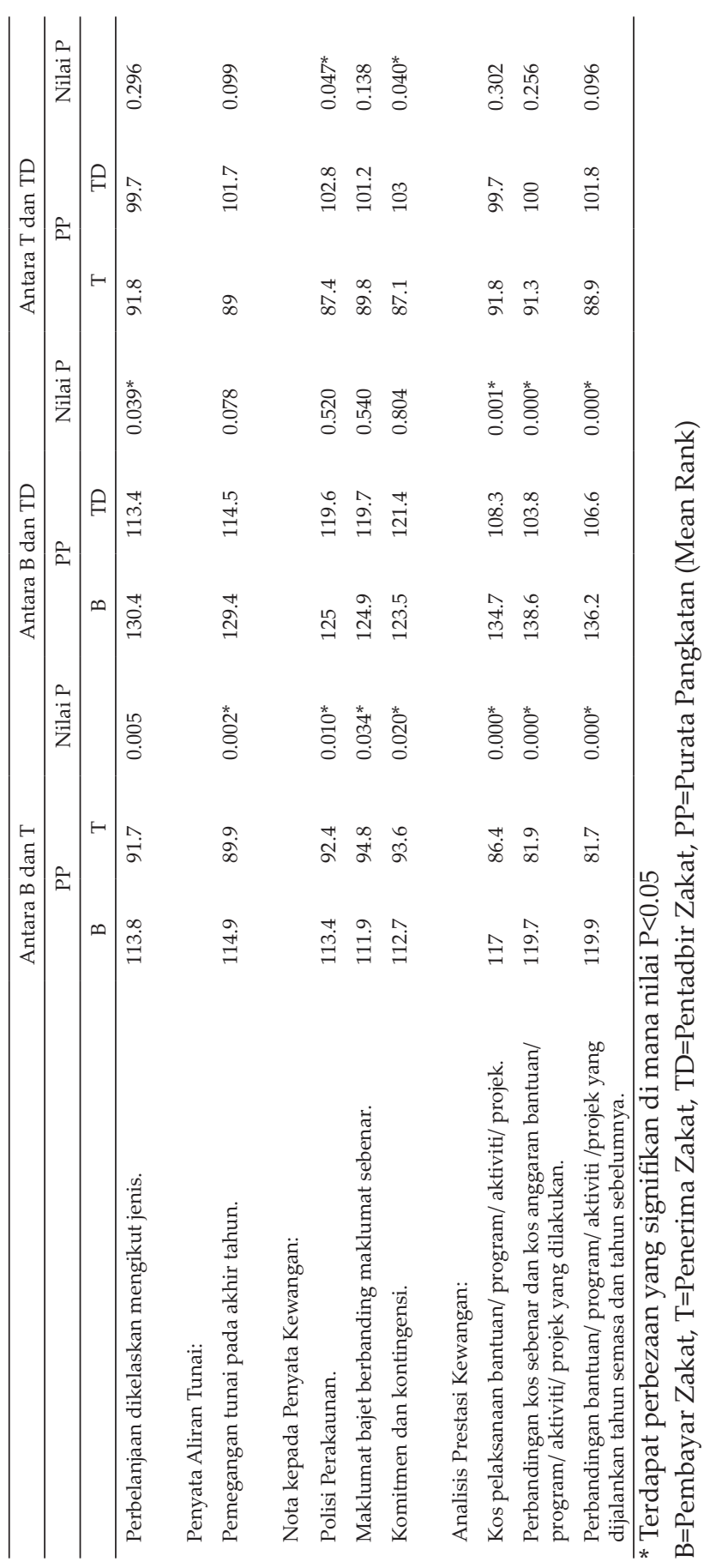


Jadual 5 menunjukkan pembayar zakat lebih mengutamakan maklumat korporat, laporan pengerusi, maklumat prestasi perkhidmatan maklumat, Sijil dan laporan ketua audit negara, maklumat penyata pendapatan dan perbelanjaan, penyata aliran tunai (item maklumat pemegangan tunai pada akhir tahun) dan maklumat analisis prestasi kewangan berbanding penerima dan pentadbir zakat. Dapatan kajian ini selari dengan kajian Connolly dan Dhanani (2009) dan Connolly dan Hyndman (2003) di mana bagi organisasi kebajikan, maklumatmaklumat berkaitan kewangan dan prestasi perkhidmatan sangat dipentingkan oleh penderma iaitu pemegang kepentingan yang menyalurkan dana kewangan. Manakala pentadbir zakat lebih mementingkan maklumat penyata lembaran imbangan (item maklumat aset semasa dan liabiliti semasa) dan penyata aliran tunai (item maklumat aliran tunai dari operasi). Bagi penerima zakat didapati kurang mementingkan maklumat pelaporan prestasi berbanding pembayar dan pentadbir zakat.

\section{Kesimpulan}

Secara keseluruhan kajian ini mendapati maklumat kewangan dan maklumat bukan kewangan adalah penting untuk didedahkan di dalam pelaporan prestasi institusi zakat iaitu maklumat korporat, laporan pengerusi, penyata kewangan-lembaran imbangan, penyata kewangan-penyata perubahan ekuiti, penyata kewangan-penyata aliran tunai, penyata kewangan-nota kepada akaun, analisis prestasi kewangan dan nisbah prestasi kewangan. Penekanan diberikan kepada maklumat sijil dan laporan ketua audit Negara, penyata pendapatan dan perbelanjaan, maklumat prestasi perkhidmatan dan maklumat perancangan. Secara khusus mengikut kumpulan pemegang kepentingan, terdapat perbezaan yang signifikan bagi keperluan maklumat pemegang kepentingan terhadap maklumat prestasi perkhidmatan, maklumat sijil dan Laporan Ketua Audit Negara dan maklumat penyata pendapatan dan perbelanjaan. Penerima zakat walau bagaimanapun didapati kurang mementingkan maklumat tersebut berbanding pembayar dan pentadbir zakat.

Kajian ini terhad kepada pembayar dan penerima zakat yang meliputi empat buah negeri sahaja iaitu Wilayah Persekutuan, Selangor, Perak dan Terengganu. Adalah dicadangkan kajian ini diperluaskan ke seluruh negeri di Malaysia. Selain itu, memandangkan pemegang kepentingan amat mementingkan maklumat sijil dan laporan Ketua Audit Negara untuk memastikan penyata kewangan yang 
didedahkan telah disediakan dan dipersembahkan mengikut piawaian yang diterima pakai, diamalkan secara konsisten, seragam serta pendedahan yang mencukupi, adalah dicadangkan kajian ini diperluaskan dengan mengkaji kualiti pendedahan maklumat penyata kewangan di dalam pelaporanprestasi institusi zakat. Pendekatan kuantitatif kaedah tinjauan soal selidik yang digunakan dalam kajian ini tidak dapat menerangkan mengapa pemegang kepentingan menganggap item maklumat tertentu penting dan perlu diplaporkan, atau sebaliknya. Kajian masa hadapan harus mengambilkira pendekatan seperti temubual dengan pemegang kepentingan terpilih untuk mendapatkan penjelasan dan pandangan merekea berkaitan keperluan terhadap item maklumat pelaporan prestasi institusi zakat.

Hasil kajian ini diharapkan dapat memberi sumbangan secara teoritikal dan praktikal. Secara teoretikal melalui pengembangan ilmu pengetahuan dari segi teori akauntabiliti dan teori pemegang kepentingan dengan mengaitkan maklumat yang diperlukan oleh pemegang kepentingan institusi zakat dalam pelaporan prestasi. Secara praktikal, kajian ini mencadangkan maklumat-maklumat yang perlu dilaporkan dalam pelaporan prestasi institusi zakat mengikut keperluan pemegang kepentingan utama iaitu pembayar, penerima dan pentadbir zakat. Pelaporan prestasi yang mengambilkira keperluan pemegang kepentingan dilihat dapat memberikan kesan yang positif dalam tadbir urus awam dan menjadi alat untuk menjelaskan akauntabiliti institusi zakat kepada pemegang kepentingannya. Hasil kajian boleh dijadikan panduan kepada pihak institusi zakat dan agensi kerajaan lain bagi meningkatkan ketelusan dan memperkasakan akauntabiliti dalam mencapai urus tadbir ekonomi yang adil, selari dengan objektif Program Transformasi Ekonomi (ETP) di bawah Program Transformasi Kerajaan (GTP) dalam mencapai wawasan 2020.

\section{Rujukan}

Abdul Rahim Abdul Rahman. . (2007). Pre-requisites for effective integration of zakah into mainstream Islamic financial system in Malaysia. Islamic Economic Studies,14 (1\&2), 91-107.

Azman Ab Rahman, Mohammad Haji Alias, \& Syed Mohd Najib Syed Omar. (2012). Zakat institution in Malaysia: Problems and issues. Global Journal Al-Thaqafah, 2(1), 35-41.

Canadian Institute of Chartered Accountants (CICA). (2011). Improved annual reporting by not-for-profit organizations. 
Cohen, S., \& Karatzimas, S. (2014). Reporting performance information in the public sector: The moral behind the (non) application of program budgeting in Greece. International Review of Administrative Sciences, 80(3), 619-636.

Connolly, C., \& Dhanani, A. (2009). Narrative reporting by UK charities. London.

Connolly, C., \& Hyndman, N. (2003). Performance reporting by UK charities: Approaches, difficulties and current practise. Scotland.

Connolly, C., Hyndman, N., \& McConville, D. (2012). Research in charity accounting and reporting: A fertile field for exploration. Irish Accounting Review, 1-31.

Coy et al. (2001). Public accountability: A new paradigm for College and University annual report. Critical Perspectives on Accounting, 12, 1-31.

Daniels, J. D., \& Daniels, C. E. (1991). Municipal financial report: What users want? Journal of Accounting and Public Policy, 10(1), 15-38.

Engku Ismail et al. (2006). Perakaunan sektor awam di Malaysia. Sintok, Kedah: Universiti Utara Malaysia. (LENGKAPKAN NAMA PENULIS.

Engku Ismail, E. A., Mohamad Sharofi, I., Syed Soffian, S. I., Siti Zabedah, S., \& Zarifah, A. (2011). Perakaunan sektor awam di Malaysia. Sintok, Kedah: Penerbit Universiti Utara Malaysia.

Freeman, R.E. (1984). Strategic Management: A Stakeholder Approach. Boston: Pitman Publishing.

Gray, A., \& Jenkins, B. (1993). Codes of accountability in the new public sector. Accounting, Auditing and Accountability Journal, 6(3), $0-0(1)$

Groot, T., \& Budding, T. (2005). New public management's current issues and future prospects. Financial accountability and management, 2008 - Wiley Online Library

Grosso, A. L., \& Ryzin, G. G. Van. (2011). How citizens view government performance reporting results of a national survey. Public Performance and Management Review, 35(2), 235-250.

Hairunnizam \& Radiah. (2010). Localization of Malaysia zakat distribution: Perception of amil and zakat recipients. Proceeding of Seventh International Conference The Tawhidi Epistemology: Zakat and Waqh economy.

Hairunnizam, W., Sanep, A., \& Radiah, A. K. (2009). Pengagihan zakat oleh institusi zakat di Malaysia: Mengapa masyarakat Islam tidak berpuas hati. Jurnal Syariah, 17(1), 89-112.

Hameed, S. (2000). The need for Islamic accounting: Perception of its objectives and characteristics by Malaysia accountants and academics. Ph.D. Thesis. University of Dundee. 
Hasan, B., \& Syawal, K. (2007). Amalan "Corporate Governance" dalam pengurusan institusi zakat di Malaysia. Jurnal Pengurusan Jawhar, 1(2), 53-70.

Hooks, J., Tooley, S., \& Norida, B. (2012). An index of best practice performance reporting for Malaysian local authorities. Journal of Applied Accounting Research, 13(3), 270-283.

Htay, S.N.N., \& S.A. Salman. (2014). Proposed best practices of financial information disclosure for zakat instituition: A case study of Malaysia. World Applied Sciences Journal 30 (Innovation challenges in multidisciplinary research and practice), 288-294.

Hyndman, N. S., \& Anderson, R. (1995). The use of performance information in external reporting: An empirical study of UK executive Agencies. Financial Accountability dan Management, 11(1).

IFAC (1996). Performance Reporting by Government Business Enterprises: The provision of Financial and Non Financial Performance Information in General Purpose Financial Reports (IFAC, New York)

IFAC (2011). Reporting Service Performance Information. Consultation Paper, Oktober 2011.

Krejcie, R. V., \& Morgan, D. W. (1970). Determining sample size for research activities. Educational and Psychological Measurement, 30, 607-610.

Lapsley, I. (1992). User needs and financial reporting: A comparative study of local authorities and the national health services. Financial Accountability dan Management, 8(4), 281-98.

Mahmood Zuhdi. (2003). Pengurusan Zakat. Kuala Lumpur: Dewan Bahasa dan Pustaka, Malaysia.

McDavid, J. C., \& Huse, I. (2011). Legislator uses of public performance reports: Findings from a five-year study. American Journal of Evaluation, 33(1), 7-25.

Mohamad Dahan. (1998). Zakat management and administration in Malaysia. Paper presented at Seminar of zakat and taxation at Universiti Islam Antarabangsa Malaysia.

Mohamad Hussain, A.B.R. (2001). Consumer centric knowledge management in zakat institutions as strategic approach to reduce poverty. Consumer-Centric Knowledge Management, Saudi Arabia: Taibah University.

Mohammed et al. (2012). Zakat distribution and growth in the Federal Territory of Malaysia. Journal of Economics and Behavioral Studie, 4 (8), 449-456.

Murtala Oladimeji Abioye Mustafa. (2008). Accounting for zakat disbursement an exploratory study of empowerment schemes in 
zakat institutions. Msc. Thesis. International Islamic University Malaysia.

Neale, A., \& Anderson, B. (2000). Performance reporting for accountability purposes-lessons, issues, future. Papers presented at International Public Management Workshop, Wellington, New Zealand.

Norazlina, A. W., \& Abdul Rahim, A. R. (2011). A framework to analyse the efficiency and governance of zakat institutions. Journal of Islamic Accounting and Business Research, 2(1), 43-62.

Norida, B. (2010). An Investigation Into The Performance Reporting Practices and Accountability of Malaysian Local Authorities. PhD Thesis

Patmawati, H. I. (2008). Pembangunan ekonomi melalui agihan zakat: Tinjauan empirikal. Jurnal Syariah, 16(2), 223-244.

Qardhawi, Y. (2007). Hukum zakat (Salman Harun, Didin Hafidhuddin dan Hasanuddin, Terjm.10 ed.). Bogor: Pustaka Litera AntarNusa.

Reid, T. E., \& Adibe, M. O. (1976). The role of performance information in improving the management of public sector programs.

Saldanha, C. (2004). Promoting results-based management in the public sectors of developing countries. Governance And Regional Cooperation, 1(4), 1-4.

Sheila Nu Nu, H., \& Syed Ahmed, S. (2014). Proposed best practices of financial information disclosure for zakat Institutions: A case study of Malaysia 30, 288-294.

Stoetzer, S., Hilger, D., (2011). Stakeholder performance reporting for nonprofit organizations. International Journal of Business Research, (11)2, 83-97.

Suhaiza., \& Nur Barizah (2011). Reporting practices of Malaysian public universities: The extent of accountability disclosure. Journal of Business Management, 5(15), 6366-6376.

Syawal Kaslam., \& Hasan Bahrom. (2007). Amalan corporate governmance' dalam pengurusan institusi zakat di Malaysia. Jurnal Pengurusan JAWHAR,1(2),53-70.

Theresa Dunne. (2013). Governance and performance reporting in Scottish charities. Journal of Financial Reporting and Accounting, 11(2), 112-130.

Tooley, S., Hooks, J., \& Norida, B. (2009). Stkakeholders' perception on the accountability of Malaysian local authorities. Advances In Public Interest Accounting,

Tooley, S., Hooks, J., \& Norida, B. (2010). Performance reporting by Malaysian local authorities: Identifying stakeholder needs. Financial Accountability dan Management, 26 (2), 103-134.

Zaharia, P. (2012). Introduction of the new public management in the Romanian and Swiss local public administration. I (4), 70-79. 
IJMS 23 (2), 97-124 (2016)

Zahirul Hoque. (2008). Measuring and reporting public sector output/ outcomes: Exploratory evidence from Australia. International Journal of Public Sector Management, 21, 468-493.

Zainon, S., Hashim, M., Yahaya, N., Atan, R., \& Maria, K. (2013). Annual reports of non-profit organizations (NPOs): An analysis 9(2), 183-192. 